\title{
Studying the Rise and Fall of Powers: Insights From Neo-Khaldunian Thought
}

\section{El-Mekdad Gamal Shehab}

$\mathrm{Ph} . \mathrm{D}$. candidate in Islamic Thought and Islamic Civilization, International Institute of Islamic Thought and Islamic Civilization (ISTAC) International Islamic University, Malaysia

Email: shehab.elmekdad@live.iium.edu.my

\author{
Article History \\ Received: 8 January, 2021 \\ Revised: 20 February, 2021 \\ Accepted: 25 March, 2021 \\ Published: 30 March, 2021 \\ Copyright (C) 2021 ARPG \& \\ Author \\ This work is licensed under \\ the Creative Commons \\ Attribution International \\ (क) (i) \\ 4.0
}

\begin{abstract}
This paper sheds the lights on the ideas of Ibn Khaldūn in conjunction with the thoughts of Malik ibn Nabi on the rise and fall of powers and posits that the psycho-sociological analysis of Ibn Khaldūn can be applied to the rise and fall of the contemporary political powers. the paper argues that this validity stems from the comprehensiveness of the Ibn Khaldūn analysis which explains how the political power generates from the stage of the idea, flowing to the stage of states, reaching ultimately to the civilization which is the most progress status sought by any power. by combing the ideas of these two scholars, this paper proposes what can be called the "Neo-Khaldūnian" approach to study the rise and fall of the powers in the modern world.
\end{abstract}

Keywords: Politics dynamics; Power dynamics; Ibn Khaldun; Neo-Khaldunian; Malik ibn Nabi.

\section{Introduction}

The concept of power has been described as "the most fundamental in the whole of political science" (Lasswell and Kaplan, 1965) and the currency of politics (Mearsheimer, 2013) the centrality of the principle of power in political relations stems from the internal tendency of a man wanting to dominate and control others, so the dispute over power has historically been a ferocious and complex process. To find an example of this, one needs to look no further than the creation story of Adam and Eve, where the sin which resulted in Adam being expelled from the Garden of Eden was his quest for power (what is referred to as Original Sin in the Christian tradition). While this story is normally associated with the Judeo-Christian tradition, Islam also provides a similar narrative. It is stated in the Qur'an that,

"But Satan whispered evil to him: he said, "O Adam! Shall I lead thee to the

Tree of Eternity and to a kingdo006D that never decays?" (Quran 20:120).

Therefore, understanding the nature of power, its sources, the factors influencing it, and its mechanisms of operation within space and time, are what enable us to correctly understand the structure of governance within that domain, explain political events that have occurred or are occurring, and to also predict their potential consequences.

Due to the importance of the concept of power scholars have attempted to present theories and analyses to explain the circular movement of the rise and fall of powers, and the scope of these theories and specific areas of interest have varied, while some of these theories are concerned with civilizations (Goldman, 2011; Spengler, 1932; Toynbee, 1939), others are concerned with the rise of powers and empires in the international arena (Kennedy, 1987) while others focus on the rise and failure of nations and societies (Acemoglu and Robinson, 2013; Bremmer, 2007; Diamond, 2011). One of the first to notice and contribute to explaining this trend was Ibn Khaldun in his cyclical theory of the state.

Nevertheless, almost all scholars have agreed that transitions of power are inevitable and permanent in history. They also have noted that throughout history civilizations, empires, and states have all been condemned to decline and subsequently fall (Ferguson, 2010).

There is a prerequisite for any approach that tries to explain the dynamics of power politics, it must first consider the various factors affecting the circular movement of the rise and fall of powers in politics, and to avoid causal monism in explanation. This essay argues that Ibn Khaldun's theory meets this precondition. and To prove that, this paper has been divided into two parts. In the first part, a critical review is provided of the literature that tried to use Ibn Khaldun's theory in the modern era, while the second part presents the "Neo-Khaldunian" approach based on the works of Algerian philosopher Malik bin Nabi the developer of the khaldunian thoughts in the modern time. 


\section{Part 1: Khaldunian Studies between Classic and Neo-Khaldunian thinking}

The ideas of $14^{\text {th }}$-century legal scholar and politician Ibn Khaldun have impacted the study of society, politics, social change, and history for over have a millennium (Garrison, 2012). However, the works that tried to re-read his theory on the rise and fall of states in modern times are not many (Alatas, 2013) especially the studies that attempted to use Ibn Khaldun to explain contemporary politics or tried to develop it and apply his theories in contemporary cases (e.g. (Carré, 1988; Turchin, 2003) or to expand the concept of " Asābiyah " to include every social formation such as a party, group or organization, not just a tribe.

Also, it has been noted that those works didn't follow a single methodology, for example, sometimes his idea is used in a descriptive exposition (e.g., (Baali, 1992; Spengler, 1963) or at other times his ideas are used in politics, economics, and society in comparison with some Western thinkers like Max Weber, Marx and Durkheim (e.g., (Gellner, 1975; Goodman, 1972) and sometimes his ideas are used inconsistently. Ayad (1930) for example, believed that Ibn Khaldun was attempting to "subordinate religion to his own scientific theories" while (Gibb, 1933), in his work titled The Islamic Background of ibn Khaldun's Political Theory proved that Islam was deep at the roots of ibn Khaldun's political theory.

It is, therefore, possible to say that because of Ibn Khaldun's diffuse and contradictory approach, this led to the lack of accumulation of this literature towards the production of one coherent approach for Ibn Khaldun capable of interpreting any contemporary political phenomenon.

Despite the early (Carré, 1988) talk about the Neo-Khaldunian approach but the attempts that have practically done so remained few, the most important of which is the attempt by Farid Alatas to re-introduce Ibn Khaldun was done through the many papers which have been culminated in his two latest books in 2013 and 2014.

Alatas assumes that the Khaldunian project is essentially the historical sociology of state formation, He also thinks Ibn Khaldun's thought can be used to analyze "societies for which kin- based solidary groups were important in state formation" (Alatas, 2014). In his book “Applying Ibn Khaldun” Alatas tried to apply Ibn Khaldun's theory to four cases of ancient and modern study, namely the Ottoman Turkey, Safavid, Iran, Saudi Arabia, and modern Syria.

Despite this advanced attempt, that Alatas carried on in the style of classical thinking in the direction of Ibn Khaldun (Alatas, 2014). For example, Alatas complains about the lack of application of Ibn Khaldun's theory to the study of economics, therefore we find Alatas incorporating Ibn Khaldun's ideas with the idea of Marx's mode of production (Alatas, 2014).

In this way, Farid Alatas did not present in his work a Neo-Khaldunian approach but presented Ibn Khaldun in the same classical form and that should make us ask what is the essence of the difference between the classical way of thinking towards Ibn Khaldun and the Neo-khaldunian perspective?

The difference is the degree of understanding that the essence of Ibn Khaldun's approach was essentially a psycho-sociological approach, and thus all the previous literature was unable to develop new ideas that could work in on contemporary issues and remained locked in the traditional classical thinking of its theory. The difference between the classical and Neo-Khaldunian approach can be understood by shedding light on the key concepts of Ibn Khaldun's political dynamism, which is the "Bedouin-civilization" cycle.

According to the psycho-sociological lens, when Ibn Khaldun spoke about Bedouin and civilization, spoke of them as different environments that lead to a different psyche, personality, and a different lifestyle. The main unit of analysis was the "psychological and lifestyle" of those environments rather than the environment itself. Where the "nomadic lifestyle" refers to discipline, seriousness, and sacrifice, whereas the "civilian lifestyle" being more complex and more comfortable, and more dependent on others. From this angle, Ibn Khaldun determined the nomadic psyche is responsible for the rising of nations, and the civil psyche is responsible for its collapse. However, the difference between the present time and the time of Ibn Khaldun is that in the time of Ibn Khaldun the "psychic of the Bedouins" grew only in the Bedouin environment, and the "urban psyche" flourished only in the urban environment. Accordingly, without any exaggeration, this psycho-sociological perspective could enable us to use Ibn Khaldun's ideas in contemporary times, by rereading his theory of the rise and fall of powers to become as follows:

Any religious idea, world view, or political ideology is intentionally achieved by changing the general morals of individuals to create a "Bedouin psyche," or use it if it exists. The "nomadic psyche" is characterized by personal and moral qualities such as commitment, discipline, seriousness, and sacrifice. Of the total number of individuals who carry this "nomadic psyche", a new social network is created in the society called "Asābiyah "or "social solidarity" that achieves unity and cohesion among those who believe in this idea, whether in the form of a party, group, organization, association, or tribe. This "tribalism" interacts with other tribality powers in the same society, and in the political conflict with "the psyche Bedouin" will defeat those who carry a "civilian psyche ", and they will seize power and remain until the generation loses that "nomadic psyche", and so on. 


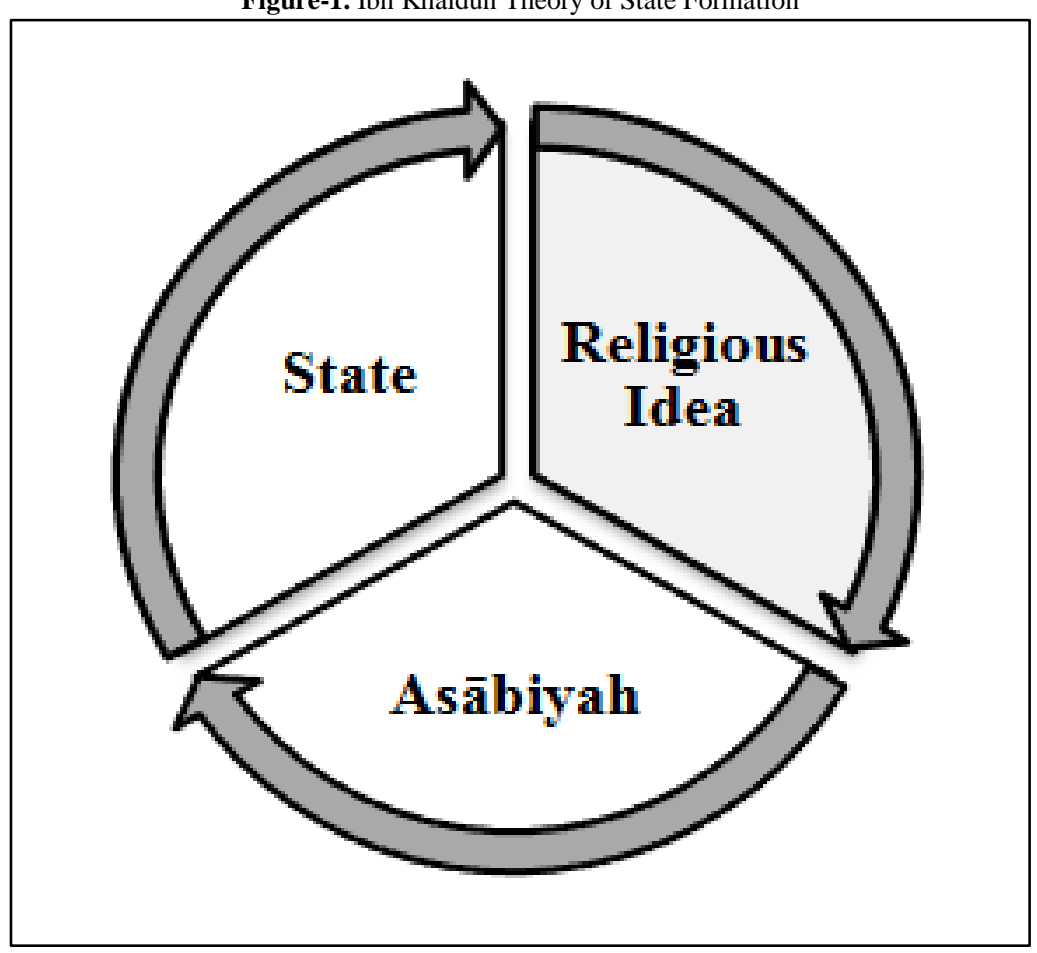

The following table illustrates the major differences between the classical Khaldunian and the Neo-Khaldunian approaches:

Table-1. A comparison between the classical and neo-khaldunian approaches to Ibn Khaldun theory

\begin{tabular}{l|l|l}
\hline Core Differences & $\begin{array}{l}\text { The classical approach to } \\
\text { Ibn Khaldun Theory }\end{array}$ & $\begin{array}{l}\text { Neo-Khaldunian approach to Ibn } \\
\text { Khaldun theory }\end{array}$ \\
\hline Nature of Approach & Material approach & Psycho-sociological approach \\
\hline $\begin{array}{l}\text { The interpretation } \\
\text { of the "Bedouin- } \\
\text { civilization" cycle }\end{array}$ & $\begin{array}{l}\text { A conflict between the } \\
\text { Bedouin and the urban } \\
\text { environments. }\end{array}$ & $\begin{array}{l}\text { A conflict between the psychological and } \\
\text { moral pattern of the Bedouin way of life on } \\
\text { one side, and between the psychological and } \\
\text { moral style and the way of urban life on the } \\
\text { other. }\end{array}$ \\
\hline $\begin{array}{l}\text { The main unit of } \\
\text { analysis }\end{array}$ & Tribalism & $\begin{array}{l}\text { The psychological and sociological impact } \\
\text { of the religious idea on the individual's } \\
\text { ethics and then on the structure of society. }\end{array}$ \\
\hline
\end{tabular}

\section{Part 2: Toward a Neo-Khaldunian Approach}

in this part the ideas presented will be the main ideas of Malik bin Nabi who was the only scholar able to benefit from Ibn Khaldun and develop his ideas toward a new understanding of his theories. The difference between Malik bin Nabi and all previous works on Ibn Khaldun is the understanding of the essence of the theory of Ibn Khaldun as a psycho-sociological theory based on the initial religious idea, and the impact of that idea in the psyche of the individual and society, starting from the right point to build his theory in civilization, Malik bin Nabi could be considered the first authentic Neo-Khaldunian.

Most of Bin Nabi's works were trying to analyze the reasons behind the rise of western civilization and the decline of the Islamic one. Compared to other approaches, Bin Nabi is in the middle of the spectrum, asserts that both moral and material factors are crucial in the civilization process. His main ideas about power dynamics could be summarized as below:

\subsection{The Equation of Civilization Process}

According to Bin Nabi, the civilization process is a psych-social transformation that could not happen without a dynamic interaction between the historic organic syntheses of three factors: man, soil, and time, within the framework of religion. All civilizations, without exception, in history have flourished among religious ideas. The three elements found in every society are the fundamentals for a society to begin a civilizing process. Bin Nabi stated that civilization rises with the integrated type of man who transforms his characteristics into his ideals to undertake his role in society. According to Bin Nabi, the civilization starts with a religious idea that leads to the development of behavior and ethics in the person, forcing him to commit himself to this idea, leading to the emergence of a new social network that reconstructs and organizes this idea in society in Bin Nabi's approach, without the construction of human personality, soil exploitation, and time organization, religion cannot begin its civilizing function as a catalyst (Benlahcene and Lake, 2013). 


\section{Religion \\ Man $\boldsymbol{4}$ Soil $\mathbf{m}$ Time $\Rightarrow$ Civilization}

Nonetheless, the soil in Malik bin Nabi's terms refers to the material factors, while time refers to Chronological space where all Human, Material, and moral factors interacting together producing a civilization, according to Malik Bin Nabi the balance between those three elements of civilization accelerates the emerging of civilization and vice versa.

\subsection{The Cycle of Civilization (Soul - Reason - Instinct)}

Bin Nabi developed his idea of the cycle of civilization based on the theories of Ibn Khaldun. Bin Nabi proposed three stages which a civilization goes through beginning with the pre-civilized stage, then the civilized state, and finally the post-civilized stage. Bin Nabi goes into further detail as he subsequently breaks down the civilized stage into three subcategories the soul (the spiritual), reason (the rational), and instinct (the instinctive). According to Bin Nabi, the journey a civilization goes through starts with religious ideas that plant the seeds for the spiritual phase of society. During this stage, the disintegrated man will change to an integrated man, and his instincts are under the control of his new spiritual compass.

The reverse process, the process of falling, occurs when the societies enter the stage of instinct. where instinct controls the rational and spiritual one. For Bin Nabi, after a society has stopped adhering to its religious moral compass, it will lose its way and its collapse will begin (Benlahcene and Lake, 2013).

Also, Malik bin Nabi was greatly influenced by Ibn Khaldun, this can be easily demonstrated by looking at the similarity between the two scholars in the following three points:

1. Firstly, both are seeing the primacy of religious ideas in the emergence of major political changes.

2. Secondly, both share the same idea of "social solidarity" where Ibn Khaldun's tribalism is social solidarity, which occurs because of the association of a human group with a particular idea. where Malik bin Nabi calls it "social network".

3. Thirdly, both believed in the cyclical movement in the rise and fall of states, which is related to the transformation in the psychology of a people.

As for the points of difference between Malik bin Nabi and Ibn Khaldun, it can be said that Malik bin Nabi went far beyond what was covered by Ibn Khaldun.

Figure-3. Malik Bin Nabi theory in Civilizations formation

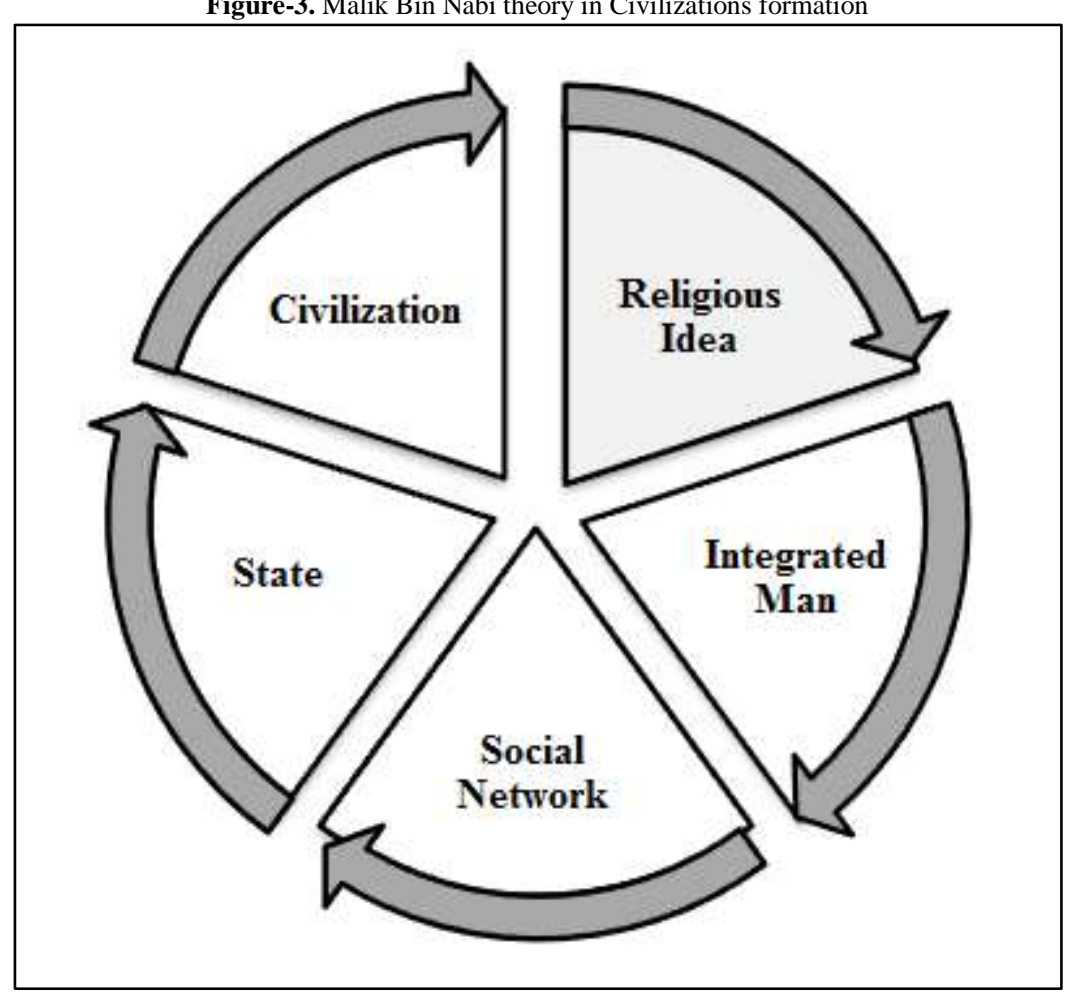

In conclusion, the Neo-Khaldunian approach can thus be presented as follows:

The prerequisite that must be in place before an entity becomes a political power is a religious worldview, or another ideology, that acts as an impetus that evokes people to change. These individuals, who have changed their morals and become integrated men, begin to form a "group" or a new social network that checks the social solidarity 
and coherence and unites that idea with a tribe, ethnicity, religion, organization, or party. With the new-found idea linked with a social force, this then leads to the formation of political power, which is expressed and transferred from the local level within a given society to the regional level or global level depends on the level of achieving the balance between all factors of power (Moral, Material and Human factors) or between Man, soil and Time, Moreover, the higher-achieving of the balance, the greater its ability to reach the stage of civilization. Where this stage of civilization is the maximum stage sought by any power, the decline is then inevitable (Ibn Khaldūn, 1967), and begins to fade as soon as the spirit of that civilization is lost (Benlahcene and Lake, 2013).

The following chart illustrates the Neo-khaldunian approach and demonstrates its comprehensiveness.

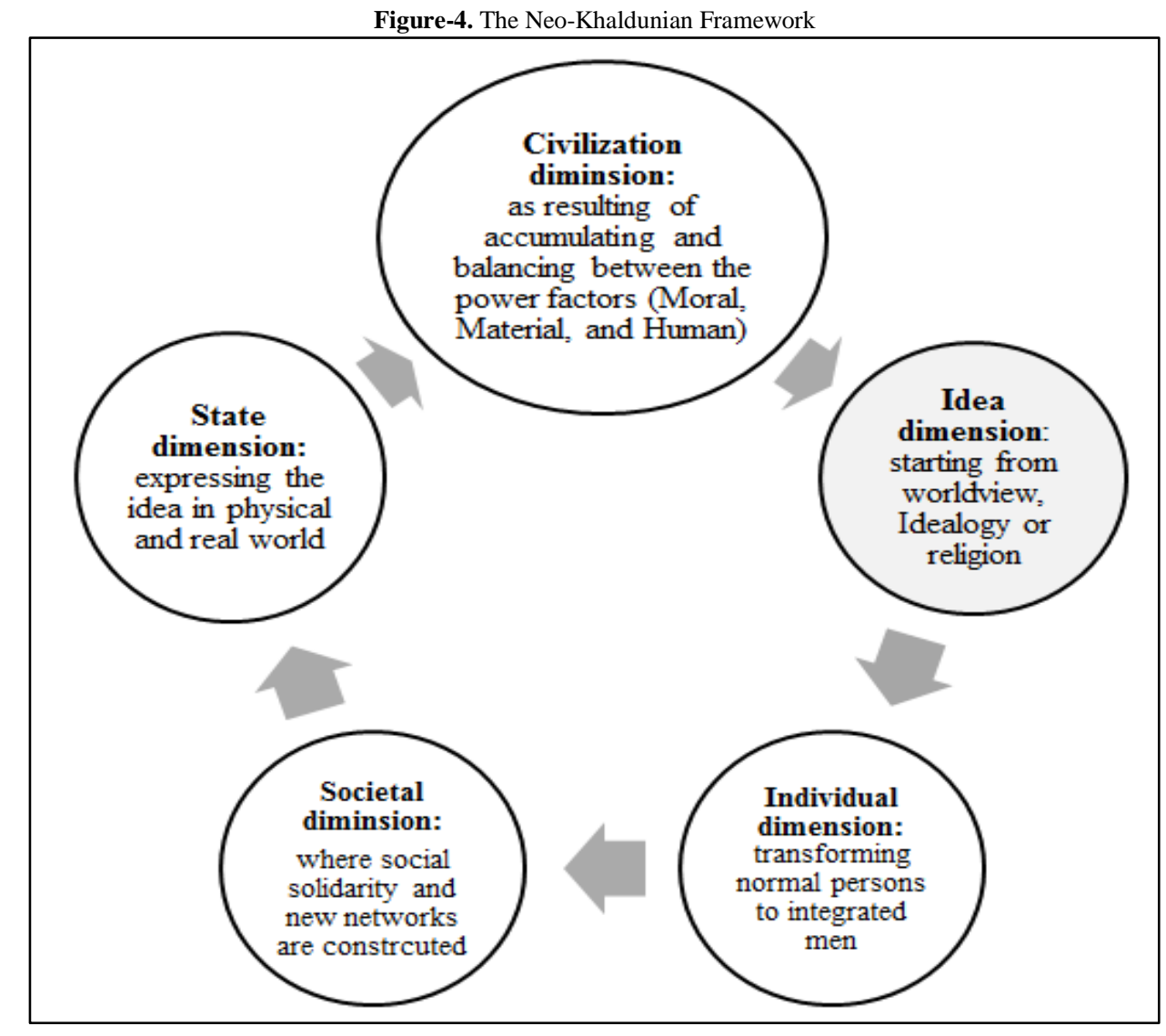

\section{Conclusion}

This paper attempted to produce a new understanding of the classical Ibn Khaldun theory of state formation, it proposes a new framework that could give an insight on explaining the rise and fall of powers in modern politics. The findings of this paper could be pointed out in three points:

First, the Neo-Khaldunian approach sees the logic of political power at the local, or international level as one where civilization is the maximum stage sought by any power, the decline is then inevitable. The rise of powers as a process begins with the idea and then by the influence that this idea has on the psychology of the individual and society, leading to the change of his social network. The local or global level depends on the ability to strike a balance between the three factors (material, moral, and human) or soil, time, and man in terms of Malik bin Nabi.

Second, the modern works on Ibn Khaldun failed in crystallizing a comprehensive approach, despite the attempts of some like Alatas $(2013 ; 2014)$, they continued in the traditional scope of Ibn Khaldun, while this paper presents the keys to the creation of the Neo-Khaldunian approach based on Psyche-sociological perspective, which was first propounded by Malik bin Nabi.

Thirdly, this new framework needs to be tested more deeply, to examine its explanatory capacity, both at the local level and international level. The study, therefore, invites researchers to build on the approach in this paper and to help improve it.

\section{References}

Acemoglu, D. and Robinson, J. A. (2013). Why nations fail: The origins of power, prosperity, and poverty. Profile Books: London.

Alatas, S. F. (2013). Ibn Khaldun. Oxford University Press: New Delhi.

Alatas, S. F. (2014). Applying Ibn Khaldun: The recovery of a lost tradition in sociology. Routledge: London and New York.

Ayad, M. K. (1930). Die geschichts- und gesellschaftslehre Ibn Haldūns. Berlin: Cotta.

Baali, F. (1992). Social institutions: Ibn Khaldun's social thought. University Press of America: Lanham. 
Benlahcene, B. and Lake, A. (2013). The socio-intellectual foundations of Malek Bennabis's approach to civilization. International Institute of Islamic Thought: Herndon, VA.

Bremmer, I. (2007). The J curve: A new way to understand why nations rise and fall. Simon and Schuster Paperbacks: New York.

Carré, O. (1988). Apropos de vues néo Khalduniennes sur quelques systèmes politiques Arabes actueles. Arabica, 35(3): 368-87.

Diamond, J. M. (2011). Collapse: How societies choose to fail or succeed. Penguin: London.

Ferguson, N. (2010). Complexity and collapse: Empires on the Edge of Chaos. Foreign Affairs, 89(2): 18-32.

Garrison, D. H. (2012). Ibn Khaldun and the modern social sciences: A comparative theoretical inquiry into society, the state, and revolution. Yüksek Lisans Tezi, The Faculty of Josef Korbel School of International Studies, Denver Üniversitesi, ABD. Available: https://www.researchgate.net/publication/259864574_Ibn_Khaldun_and the_Modern_Social_Sciences_A_ Comparative Theoretical_Inquiry into_Society the State and Revolution?ev=prf high

Gellner, E. (1975). Cohesion and identity: The maghreb from Ibn Khaldun to emile durkheim. Government and Opposition, 10(2): 203-18.

Gibb, H. A. R. (1933). The Islamic Background of Ibn Khaldūn's political theory. Bulletin of the School of Oriental and African Studies, 7(01): 23-31.

Goldman, D. P. (2011). How Civilizations Die (and why Islam is dying too). Regnery Pub: Washington, D.C.

Goodman, L. E. (1972). Ibn Khaldun and Thucydides. Journal of the American Oriental Society, 92(2): 250-70.

Ibn Khaldūn, A. (1967). The muqaddimah: An introduction to history. 3 vols.: Princeton University Press: Princeton.

Kennedy, P. M. (1987). The rise and fall of the great powers: Economic change and military conflict from 1500 to 2000. William Collins: London.

Lasswell, H. D. and Kaplan, A. (1965). Power and society: A framework for political inquiry. Yale University Press: New Hawen.

Mearsheimer, J. (2013). Structural realism. International relations theories: Discipline and diversity. 3rd edn: Tim Dunne, Milja Kurki, and Steve Smith, eds, Oxford University Press: Oxford. 77-93.

Spengler (1932). The decline of the West. G. Allen and Unwin: London.

Spengler (1963). The economic thought of Islam: Ibn Khaldun. Comparative Studies in Society and History, 6(3): 268-306.

Toynbee, A. (1939). A Study of history. Oxford University Press: London.

Turchin, P. (2003). Scientific prediction in historical sociology: Ibn Khaldun meets Al Saud. In P. Turchin, L. Grinin, V. C. de. 